\title{
Hormigón de altas prestaciones basado en aglomerantes poliméricos
}

\section{High performance polymer concrete}

\author{
J. T. San-José(*) y M. Frías ${ }^{(* *)}$
}

Recepción/Received: 21-IX-05

Aceptación/Accepted: 21-XII-06

\section{RESUMEN}

Este trabajo de investigación aborda el estudio de un hormigón de altas prestaciones, formado por áridos naturales y un aglomerante orgánico constituido por una resina termoestable poliéster, denominado hormigón polimérico HP. Se describe el material a nivel microscópico y macroscópico, presentando sus propiedades físicas y mecánicas fundamentales, mediante diferentes técnicas experimentales, tales como: porosimetría de mercurio, microscopía electrónica (SEM-EDAX), difracción de rayos X (DRX) y ensayos mecánicos (módulo de elasticidad, curvas tensión-deformación y resistencias últimas).

Como consecuencia del estudio experimental llevado a cabo, se ha podido apreciar cómo el HP está formado por porosidad cerrada del $4,8 \%$, proporcionando una elevada continuidad a su microestructura interna, lo que justifica, en parte, la mejora de propiedades mecánicas respecto al hormigón tradicional, con unos valores medios de resistencia a compresión de $100 \mathrm{MPa}$ y superiores a $20 \mathrm{MPa}$ en su resistencia a flexotracción. Debido a la falta de estandarización, se ha concluido cómo el ensayo de flexión puede ser un procedimiento adicional al de compresión, a la hora de establecer las clases resistentes del HP.

Palabras clave: hormigones poliméricos, resina termoestable, propiedades mecánicas, microestructura, SEM.

\section{SUMMARY}

This paper studies the performance of concrete whose chief components are natural aggregate and an organic binder $-a$ thermosetting polyester resin-denominated polymer concrete or PC. The material was examined macro- and microscopically and its basic physical and mechanical properties were determined using mercury porosimetry, scanning electron microscopy (SEM-EDAX), $X$-ray diffraction (XRD) and strength tests (modulus of elasticity, stress-strain curves and ultimate strengths).

According to the results of these experimental studies, the PC exhibited a low density (4.8\%), closed pore system and a concomitantly continuous internal microstructure. This would at least partially explain its mechanical out-performance of traditional concrete, with average compressive and flexural strength values of $100 \mathrm{MPa}$ and over $20 \mathrm{MPa}$, respectively. In the absence of standard criteria, the bending test was found to be a useful supplement to compressive strength tests for establishing PC strength classes.

Keywords: polymer concrete, thermosetting resin, mechanical properties, microstructure, SEM.

\footnotetext{
(*) Fundación Labein, Parque Tecnológico de Bizkaia, Vizcaya (España).

(**) Instituto de Ciencias de la Construcción Eduardo Torroja, CSIC, Madrid (España).
} 


\section{INTRODUCCIÓN}

El hormigón polimérico (HP) se produce por la mezcla de granulometrías, bien controladas, de áridos inorgánicos junto con una resina aglomerante. La resina más utilizada es la de poliéster insaturada, debido a sus buenas propiedades y relativo bajo costo. El hormigón polimérico es un material resistente y durable, presenta una baja permeabilidad y cura rápidamente (1). Como posible desventaja del HP está el elevado costo de las resinas (el costo de los áridos es comparativamente insignificante).

El hormigón polimérico aquí analizado es un material de construcción que comprende tres fases: inorgánica (áridos), orgánica (resina poliéster termoestable) e inerte (porosidad debida al aire ocluido producido durante su fabricación). La mayor parte de sus aplicaciones actuales se relaciona con elementos prefabricados para edificación y ciertos componentes estructurales en trabajos de obra civil, tales como losas y paneles de fachada (2).

Las propiedades del HP dependen, en gran medida, de la formulación, pero, en comparación con el hormigón convencional de cemento, puede caracterizarse por altas resistencias a compresión, tracción y flexión, mayor resistencia al impacto y a la abrasión, reducida permeabilidad al agua, resistencia a sales disolventes y otros compuestos químicos, gran resistencia a condiciones de envejecimiento (hielo-deshielo y humedad-sequedad), en general mayor resistencia a las condiciones medioambientales (3). En adición con las mejores prestaciones resistentes y de durabilidad, resulta muy fácil su puesta en obra, debido a su curado rápido y muy rápida ganancia de resistencias.

Dentro del campo de los polímeros asociados al hormigón se pueden distinguir tres tipos de materiales, cuyas respectivas estructuras porosas se presentan en la Figura 1: hormigón de cemento $(\mathrm{HC})$, hormigón modificado con polímeros (HMP), hormigón impregnado con polímero (HIP) y hormigón polimérico (HP). El HMP es un hormigón modificado con resinas de polímeros, en el que se puede considerar que la matriz aglomerante está constituida por cemento y polímero, pudiendo actuar este último como agente modificador o como co-matriz del anterior, realizándose la adición del polímero durante el amasado. El HIP consiste en la impregnación del HC con un polímero mediante la adición de un monómero, o prepolímero, dentro de las redes de poros del hormigón, una vez que ya está endurecido y la polimerización ha tenido lugar, dando lugar al cierre de la porosidad del HC. Por último, el hormigón polimérico (HP u hormigón de resina), analizado en la presente investigación, utiliza la resina como único aglomerante.

Actualmente, el HP tiene algunos inconvenientes frente al $\mathrm{HC}$ que limita sus aplicaciones. Debe entenderse que

\section{INTRODUCTION}

Polymer concrete $(P C)$ is made from a mixture of inorganic aggregate with a strictly controlled particle size distribution and a polymer resin as a binder. Unsaturated polyesters are the resins most commonly used, in light of their high performance and relatively low cost. Polymer concrete is a strong, durable, quick-setting material with low permeability (1). One possible drawback to its use is the high cost of the resins (the cost of the filler is negligible in comparison).

The polymer concrete analyzed here is a construction material consisting of three phases: inorganic (aggregate), organic (thermosetting polyester resin) and inert (porosity due to entrained air generated during manufacture). At present it is used primarily in precast building elements and certain structural components for civil works such as slabs and facade panels (2).

PC properties depend largely on how the concrete is proportioned. Its claim to higher performance compared to conventional cement concrete is based on its higher compressive, tensile and bending strengths, greater resistance to impact and abrasion, lower water permeability, and higher resistance to solvent salts, other chemical compounds, ageing (freeze-thaw and wet-dry cycles) and environmental conditions in general (3). In addition to its higher strength and durability, it is easier to place in situ due to its speedy setting and rapid acquisition of strength.

Three types of concrete-associated polymers can be distinguished: polymer-modified concrete (PMC), polymerimpregnated concrete (PIC) and polymer concrete (PC). Their respective pore structures, along with the structure for cement concrete (CC), are compared in Figure 1. $P M C$ is concrete modified with polymer resins, in which the binder matrix consists of cement and a polymer, with the latter acting as a modifying agent or co-matrix. The polymer is added during mixing. PIC consists in the impregnation of CC with a polymer via the injection of a monomer or prepolymer into the pore network of the concrete after it hardens; subsequent polymerization results in the closure of CC pores. Lastly, in polymer concrete ( $P C$ or resin concrete), the material analyzed here, the resin is the sole binder.

At this time, the use of PC is limited by certain drawbacks compared to CC. One of the chief disadvantages to $P C$ 
uno de los principales inconvenientes de los productos de HP es el alto coste, especialmente el de sus materias primas. Se están desarrollando importantes actividades de investigación (4) orientadas a la reducción del coste del hormigón polimérico, actuando sobre el control de la estructura del material encaminado a obtener propiedades específicas para cada aplicación.

El hormigón polimérico no protege los refuerzos de acero frente a la corrosión, como sí lo hace el hormigón de cemento debido a su alta alcalinidad mientras no esté carbonatado. Por lo tanto, el acero del armado del hormigón polimérico, si tiene lugar su fisuración y prevalece la corrosión ambiental, debería ser utilizado con su correspondiente protección frente a la corrosión. El uso de varillas de polímero reforzados con fibras (PRF), en sustitución de las varillas de acero del hormigón armado, ha surgido como una de las muchas técnicas propuestas para incrementar la durabilidad de las estructuras de hormigón armado (5). En particular, las varillas de PRF ofrecen un gran potencial para su uso en el hormigón armado, bajo unas condiciones en las que las varillas de acero convencionales han producido resultados inaceptables.

El objetivo del presente trabajo de investigación es el de analizar, desde un punto de vista microscópico y macroscópico, las oportunidades que ofrece el HP en usos estructurales, tanto para la edificación como en obra civil. Respecto al estudio microscópico, se ha optado por profundizar en un hormigón polimérico de resina poliéster ortoftálica, habida cuenta de su uso extensivo en la prefabricación, pudiendo extrapolarse sus conclusiones para el hormigón de resina poliéster isoftálica (6). En lo relativo a los estudios mecánicos, se ha estimado oportuno realizar un análisis comparativo entre dos tipos de hormigones poliméricos basados en resina poliéster isoftálica y ortoftálica, respectivamente, con similares contenidos en resina, debido a la sensibilidad apreciada anteriormente por los autores (7) en sus parámetros mecánicos fundamentales.

\section{MATERIALES Y PARTE EXPERIMENTAL}

\subsection{Materiales}

Durante el periodo de curado, las cadenas de poliéster están entrecruzadas, debido a la acción de un promotor (agente de curado). Este enlace entre cadenas es un proceso exotérmico que implica un ordenamiento relativo de los mismos, obviamente, no tan claro como el que corresponde a la naturaleza cristalina de los metales. Ambos fenómenos, ordenamiento de las cadenas y su exotermia, implican una importante retracción de la matriz de hormigón polimérico a lo largo de las primeras 5 a 7 horas, relacionadas con el tiempo de curado. Por este motivo, la resina de poliéster se dosificó con un agente anti-retracción comercial. products is their high cost, particularly as regards the prime materials. Ambitious research projects (4) are underway to reduce the cost of polymer concrete by controlling the structure to obtain properties specific to each use.

Being less alkaline than carbonation-free cement concrete, polymer concrete affords less effective corrosion protection for reinforcing steel. Consequently, the steel in polymer concrete should be protected to prevent environmental corrosion in the event of concrete cracking. The use of fibre-reinforced polymer (FRP) bars instead of the steel bars placed in reinforced concrete is one of the many techniques proposed to lengthen reinforced concrete structure durability (5). In particular, FRP bars show great promise for reinforcing concrete under conditions in which conventional steel bar performance is unacceptable.

The micro- and macroscopic analysis conducted in this study aimed to determine the possibilities of using PC in building and civil works structures. An orthophthalic polyester resin concrete was used in the microscopic study, in light of its extensive use in precasting and because the conclusions could be extrapolated to isophthalic polyester resin concrete (6). For the mechanical studies, a comparative analysis was run between isophthalic and orthophthalic polyester resin concretes with similar resin contents, on the grounds of the sensitivity of their basic mechanical parameters, identified in an earlier study (7).

\section{MATERIALS AND EXPERIMENTAL}

\subsection{Materials}

Polyester chains are cross-linked during curing in response to the action of a promoter (curing agent). This cross-chain bonding is an exothermal process that involves relative ordering of the polyesters, although obviously not as regularly as in crystalline metallic structures. This exothermal ordering of the chains entails substantial shrinkage of the polymer concrete matrix in the first five to seven hours of curing. For this reason the polyester concrete made for the present study was dosed to include a commercial shrinkage-reducing admixture. 
Las curvas granulométricas obtenidas, tras el correspondiente tamizado, deberán combinarse con el objeto de obtener el hormigón adecuado, en términos de prestaciones mecánicas y de durabilidad. El criterio de Fuller, utilizado en el presente estudio, es un patrón comúnmente aceptado para el diseño de la curva granulométrica del HP (8) y, a partir de la mezcla de áridos diseñada por esta ley, se obtiene una distribución lineal de tamaños de árido. Sin embargo, también es cierto que una curva granulométrica discontinua (la basada en la DIN 1045) conduce a un diseño de mezclas caracterizado por un HP con mayores propiedades mecánicas que las alcanzables con Fuller, aunque con peores acabados superficiales, por ser una dosificación más "abierta".

En relación con los ajustes granulométricos, la proporción de áridos es una de las decisiones más importantes para la calidad de un HP. Debido a que cada suministrador de arenas y gravas provee de diferentes curvas granulométricas, los productores de prefabricados de HP desarrollan programas específicos para calcularlas.

Por lo general, el HP ha utilizado áridos de rocas del tipo silíceo, ofítico, calizo o basáltico. Los contenidos óptimos de resina y finos han sido definidos con el objeto de obtener las mejores propiedades mecánicas. La formulación de la resina se basa en tres componentes principales:

- Resina base de poliéster y ortoftálica, producida por condensación de un glicol con dos ácidos dicarboxílicos, uno saturado y otro insaturado.

- Reactivos diluyentes, estireno, como agente de entrecruzamiento.

- Un agente de curado, adecuado para iniciar, mantener y controlar el entrecruzamiento de las cadenas de polímero. En el presente trabajo de investigación, el sistema de curado está compuesto por un promotor (sal orgánica, octoato de cobalto) y un iniciador (actuante como catalizador, metil etil cetona).

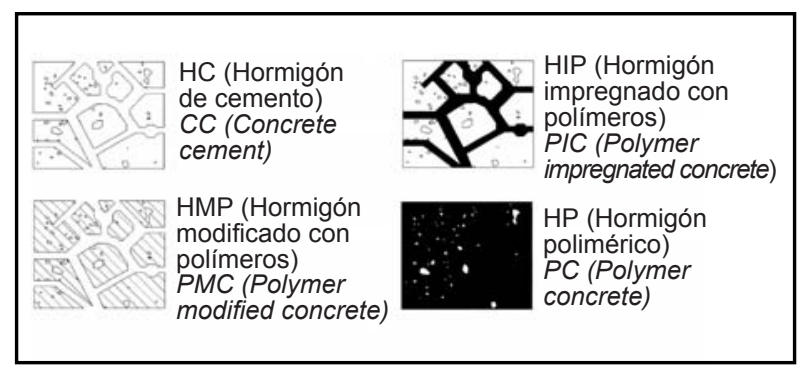

Figura 1. Esquema de la estructura de poros de la pasta ya endurecida en diferentes hormigones.

Figure 1. Pore structure of different hardened concretes.
The particle size distribution curves were found by sieving and the sieve contents were combined to obtain a suitable concrete in terms of mechanical strength and durability. The generally accepted Fuller criterion for the design of the PC particle size distribution curves was used in the present study to obtain a linear distribution of aggregate sizes (8). Be it said in this regard that a discontinuous particle size distribution curve (based on DIN 1045) provides for a mix design that yields PCs with better mechanical properties than can be attained with the Fuller pattern, although the surface finish is poorer for the more "open" grading used.

Aggregate proportioning is one of the most crucial factors in PC quality. Since every sand and gravel supplier provides different particle size distribution curves, precast PC manufacturers have developed specific programs to plot their own.

Generally speaking, PC is made with siliceous, ophitic, limestone or basalt aggregate. The optimum content of resin and aggregate fines has been defined to obtain the highest mechanical performance. Resin composition in based on three main constituents:

- Base orthophthalic polyester resin, the product obtained when a glycol is condensed with two dicarboxylic acids, one saturated and the other unsaturated.

- Diluting reagents, with styrene as the cross-linking agent.

- A curing agent to initiate, maintain and control polymer chain cross-linking. In the present study, the curing system comprised a promoter (organic salt, cobalt octoate) and an initiator (a catalyst, namely methyl ethyl ketone).

Tabla 1 / Table 1

Proporciones de mezcla del HP de poliéster ortoftálico Mix composition of orthophthalic polyester concrete

\begin{tabular}{|lc|}
\hline Componentes / Component & Contenido (\%) / Content (\%) \\
\hline $\begin{array}{l}\text { Resina de poliéster ortoftálico } \\
\text { Orthophthalic polyester resin }\end{array}$ & 12.3 \\
\hline Yeso / Gypsum & 7 \\
\hline $\begin{array}{l}\text { Polvo de cuarzo }(0.08-0.2 \mathrm{~mm}) \\
\text { Quartz powder }(0.08-0.2 \mathrm{~mm})\end{array}$ & 6.7 \\
\hline $\begin{array}{l}\text { Arena fina de cuarzo }(0.3-0.9 \mathrm{~mm}) \\
\text { Fine quartz sand }(0.3-0.9 \mathrm{~mm})\end{array}$ & 24.7 \\
\hline $\begin{array}{l}\text { Grava de cuarzo }(3.0-5.6 \mathrm{~mm}) \\
\text { Quartz gravel }(3.0-5.6 \mathrm{~mm})\end{array}$ & 49.3 \\
\hline
\end{tabular}


El estudio de la dosificación y el procedimiento de mezcla ha sido planteado mediante el análisis de la influencia de los porcentajes de resina y finos en dos aspectos del HP: resistencias (compresión y flexión) y acabado superficial (requerimientos estéticos y de durabilidad). La dosificación de HP aquí analizado se presenta en la Tabla 1.

\subsection{Experimental}

El análisis de la microestructura del HP ha sido obtenido mediante dos técnicas: porosimetría de mercurio y análisis SEM-EDAX. Los ensayos mecánicos, enfocados en el comportamiento a flexión y compresión, han sido realizados según las especificaciones establecidas en la Rilem TC 113-CPT (9).

La porosimetría de intrusión es una técnica de análisis muy común en el campo de la petrografía y la durabilidad de hormigones. Esta técnica experimental ha sido aplicada en muestras irregulares y representativas, previamente secadas en un horno a $60{ }^{\circ} \mathrm{C}$ hasta peso constante.

La microscopía electrónica de barrido ha sido realizada usando un microscopio de barrido JEOL JSM-5600 LV, con un sistema analizador EDS ISIS 300 Oxford Instrument. La preparación de las muestras, antes de colocarlas en el microscopio, consistió en cubrir las mismas con una capa de oro en condiciones de vacío ( $3 \times 10^{-2} \mathrm{mbar}$ ) durante 1 minuto y 50 segundos, y finalmente excitado a $15 \mathrm{~mA}$. Se trabajó en el microscopio a $20 \mathrm{kV}$ y a una distancia de trabajo 20 a $25 \mathrm{~mm}$.

\section{RESULTADOS Y DISCUSIÓN}

\subsection{Análisis de la microestructura}

La porosimetría de mercurio revela que el HP está formado por poros internos de tipo cerrado. Esta porosimetría fue realizada a fin de observar la interfase entre la resina y los áridos. EI HP de resina poliéster ortoftálica producido tiene una porosidad total del $4,8 \%$, así como una densidad real de $2.390 \mathrm{~kg} / \mathrm{m}^{3}$ y una densidad aparente de $2.270 \mathrm{~kg} / \mathrm{m}^{3}$, con un área de poro media de $3,484 \mathrm{~m}^{2} / \mathrm{g}$, mucho menor que los $6,040 \mathrm{~m}^{2} / \mathrm{g}$ obtenidos en un HP no estructural (orientado hacia aplicaciones estéticas/arquitectónicas). Estos valores confirman que el HP es un material más compacto que el HC (10). La distribución interna de poros y su aspecto, según el HP analizado, puede verse en la Figura 2, junto con un detalle del material (x35) tomado mediante microscopía de transmisión de luz polarizada. Debido a la microestructura cerrada que presenta el HP, éste es un material atractivo para obtener estructuras de alta durabilidad.
Dosage and mixing procedures were determined on the grounds of an analysis of the effect of the percentage of resin and fine aggregate on two PC characteristics: (compressive and flexural) strength and surface finish (aesthetic and durability requirements). The composition of the PC analyzed here is given in Table 1.

\subsection{Experimental}

PC microstructure was analyzed using two techniques: mercury porosimetry and SEM-EDAX. The mechanical tests to determine flexural and compressive strength were conducted to the specifications laid down in Rilem standard TC 113-CPT (9).

Intrusion porosimetry is an analytical technique commonly used in petrography and concrete durability. In the present study it was applied to irregular and representative samples previously oven-dried at $60^{\circ} \mathrm{C}$ to a constant weight.

A JEOL JSM-5600 LV scanning electron microscope fitted with an Oxford Instrument EDIS ISIS 300 analyzer was used for the SEM studies. The samples were vacuumcoated ( $\left.3 \times 10^{-2} \mathrm{mbar}\right)$ with gold for one minute and fifty seconds and excited at $15 \mathrm{~mA}$ prior to observation under the microscope, which was set to $20 \mathrm{kV}$; the working distance was 20 to $25 \mathrm{~mm}$.

\section{RESULTS AND DISCUSSION}

\subsection{Microstructural analysis}

Mercury porosimetry revealed that the PC had a closed system of internal pores. The technique was deployed to observe the interface between the resin and the aggregate. The orthophthalic polyester resin had a total porosity of $4.8 \%$, a real density of $2,390 \mathrm{~kg} / \mathrm{m}^{3}$ and an apparent density of $2,270 \mathrm{~kg} / \mathrm{m}^{3}$. At $3.484 \mathrm{~m}^{2} / \mathrm{g}$, the mean pore area was much smaller than the $6.040 \mathrm{~m}^{2} / \mathrm{g}$ obtained for a non-structural PC (intended for aesthetic/architectural uses). According to these values, this PC was much more compact than CC (10). The internal pore distribution in the $P C$ analyzed is shown in Figure 2, together with a detail of the material (35x) as seen under a polarized light optical microscope. Thanks to its closed microstructure, this PC is ideal for high durability structures. 
El estudio morfológico de las interfases matriz-árido fue realizado usando la microscopía electrónica de barrido (SEMEDAX). La observación de la Figura 3 evidencia la presencia de una fina capa de resina y finos (polvo de cuarzo y arena fina de cuarzo), denominada matriz, que envuelve los áridos gruesos. Las geometrías irregulares de estos gruesos incrementan su anclaje en la matriz, frente a los áridos rodados poco utilizados en este tipo de hormigones.

El análisis semicuantitativo de los componentes de resina $\mathrm{y}$ áridos fue obtenido mediante dispersión de rayos $\mathrm{X}$ (EDAX), como se representa en la Figura 3. El espectro de la mezcla de polímero analizada que se incluye indica el predominio del $\mathrm{C}$ y el $\mathrm{O}$, correspondientes a la presencia de resina de poliéster ortoftálica. Los componentes de Si aparecen debido a la presencia de áridos de cuarzo.

Como consecuencia de la estructura cerrada de poros del HP (Figura 3), frente a la tradicional abierta del HC (evacuación del agua de amasado durante su hidratación, por ejemplo), unido al hecho de que el HP tiene unos tamaños y contenidos de poros menores que el $\mathrm{HC}(8)$, hace del HP un material más compacto y competente para distribuir las tensiones internas a lo largo de su matriz (resina y finos) y áridos gruesos.

Esta continuidad microestructural, unida a la naturaleza orgánica del aglomerante, promueve la protección de los elementos del HP frente a agentes atmosféricos, corrosión y ataques químicos. El HP analizado corresponde a un hormigón de propósito estructural. Comparado con un hormigón ordinario de cemento, o con un HP de aplicación estética/arquitectónica, el HP diseñado presenta una intercara compacta (la capa de resina que envuelve a los áridos es más gruesa). En otras palabras, para futuras aplicaciones, este HP debería presentar una alta continuidad para transferir cargas $y$, consecuentemente, mostraría un comportamiento mecánico mejorado.
The matrix-aggregate interface morphology was studied under a scanning electron microscope (SEM-EDAX). Figure 3 shows coarse aggregate particles sheathed in a thin layer of matrix, consisting in a mix of resin and fine aggregate (quartz powder and fine quartz sand). The irregular geometry of the coarse aggregate enhances its anchorage in the matrix, which is why smooth aggregate is seldom used in this type of concrete.

The semi-quantitative analysis of the resin and aggregate components represented in Figure 3 was found via energy dispersive spectroscopy (EDAX). The predominance of $C$ and $O$ on the spectrum for the polymer mix analyzed is indicative of the presence of orthophthalic polyester resin. The Si components are due to the presence of the quartz aggregate.

The closed pore system in this PC (Figure 3), compared to the traditional open system found in CC (due to the evacuation of mix water during hydration, for instance), together with the smaller size and volume of the pores in the former (8) make polymer concrete a more compact material, better suited to distributing internal stress between its matrix (resin and aggregate fines) and the coarse aggregate.

This microstructural continuity, together with the organic nature of the binder, protects $P C$ members from environmental agents, corrosion and chemical attack. The PC analyzed was designed for use in structural members. Compared to an ordinary cement concrete or a PC for aesthetic/architectural use, the $P C$ in question had a compact interface (layer of resin surrounding the coarse aggregate particles). In other words, this PC should exhibit excellent load transmission continuity and consequently high strength.

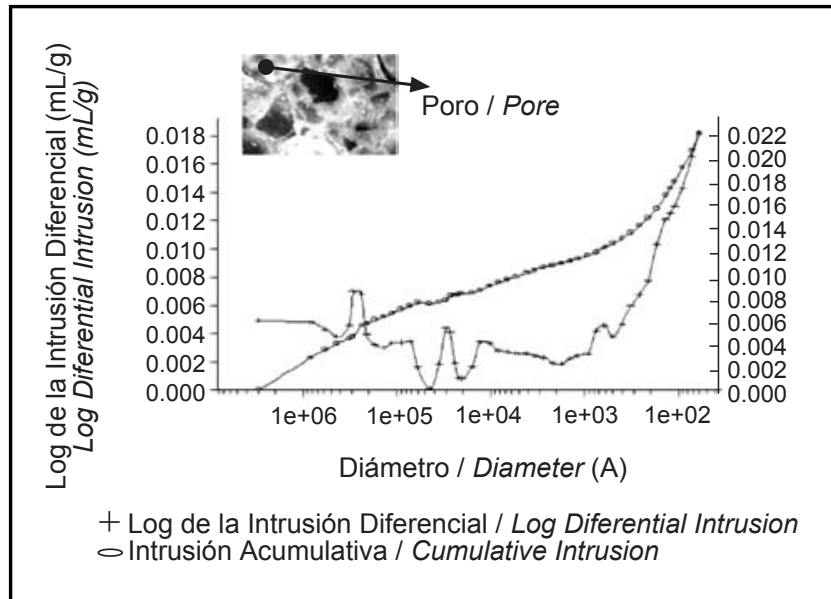

Figura 2. Análisis de porosimetría por intrusión de mercurio del HP ortoftálico. Figure 2. Mercury intrusion porosimetry analysis of orthophthalic PC. 


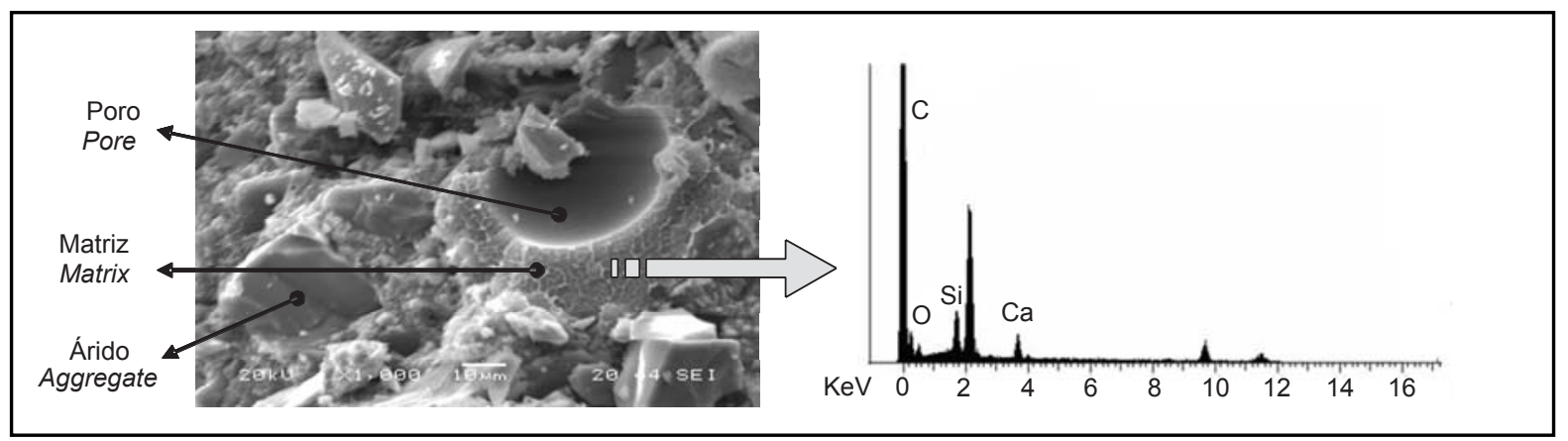

Figura 3. Microfotografía SEM del HP ortoftálico (x1.000) y Espectro EDAX del Hormigón polimérico ortoftálico (x350).

Figure 3. SEM microphotograph of orthophthalic PC (1000x) and EDAX spectrum of orthophthalic polymer concrete (350x).

\subsection{Comportamiento mecánico}

El proceso de producción de elementos de hormigón polimérico estructural requiere de plantas bien equipadas para lograr una producción continua, beneficiándose así su corto tiempo de curado. El HP puede alcanzar su resistencia representativa a compresión en $24 \mathrm{~h}$, aunque pueden hacer falta hasta 16 días para el curado completo. En el hormigón de cemento, este proceso tiene lugar durante 28 días hasta alcanzar su resistencia característica y puede continuar incrementando su valor durante algunos meses (11).

Como queda constatado en la Tabla 2 del HP ortoftálico y la Tabla 4 del HP isoftálico, el HP exhibe resistencias a tracción del orden del 25\% (15 a $25 \mathrm{MPa}$ ) del valor de la resistencia a compresión, mientras que el hormigón ordinario (6) desarrolla un máximo del $10 \%$ (2 a $7 \mathrm{MPa}$ ). En relación con la resistencia a compresión, en el caso del HP, puede variar en un amplio rango de valores, dependiendo del contenido en resina, así como del tipo de áridos.

En la actualidad, no hay definidas clases resistentes dándose variaciones considerables a la hora de utilizar diferentes tipos de resinas: poliéster isoftálico, poliéster ortoftálico, híbrido uretano-vinilester, epoxi, acrílica, etc., y tipos, grados y combinaciones de áridos. Se han realizado extensas investigaciones en Japón, USA y UE en relación con el hormigón polimérico y sus propiedades mecánicas.

Estudios previos (12) han concluido la alta dispersión en los valores de las propiedades mecánicas de los $\mathrm{HP}$, caracterizados por resistencias a compresión del orden de $100 \mathrm{MPa}$, lo que influiría en la predicción de su comportamiento estructural. Por otro lado, esto plantearía una cierta dificultad en estimar, de forma precisa, los valores de las propiedades mecánicas para hormigones poliméricos, con resistencias a compresión distintas a $100 \mathrm{MPa}$, hecho éste que sí es posible en el HC. Estas cuestiones apoyan la necesidad de estandarización del HP.

\subsection{Mechanical performance}

The manufacture of polymer concrete structural members calls for well equipped plants able to capitalize on the short curing time exhibited by the material for continuous production purposes. $P C$ may reach its representative compressive strength after just $24 h$, although full curing may take up to 16 days. By contrast, it takes cement concrete 28 days to attain its characteristic strength, and actual strength may continue to rise for several months (11).

As the values in Table 2 on orthophthalic PC and Table 4 on isophthalic PC show, the tensile strength of this material is on the order of $25 \%$ (15 to $25 \mathrm{MPa}$ ) of its compressive strength, whereas in ordinary concrete (6) the proportion is no more than $10 \%$ (2 to $7 \mathrm{MPa}$ ). PC compressive strength, in turn, may vary over a wide range of values, depending on resin content and type of aggregate used.

At this time, there are no defined strength classes and substantial variations are observed both for the different types of resins -isophthalic polyester, orthophthalic polyester, urethane-vinylester hybrid, epoxy, acrylic, and so on- and aggregate types, grades and combinations. Extensive research has been conducted in Japan, the USA and the EU in connection with polymer concrete and its mechanical properties.

Prior studies (12) found PC mechanical behaviour values to vary widely, which would impact the prediction of its structural behaviour, although compressive strength was generally on the order of $100 \mathrm{MPa}$. Moreover, this variation poses some difficulty in connection with the precise estimation of the values of polymer concrete mechanical properties for compressive strength values of other than $100 \mathrm{MPa}$; for CC, by contrast, such estimates are possible. These considerations support the case for standardizing $P C$. 
Tabla 2 / Table 2

Propiedades mecánicas en compresión y tracción del HP Mechanical properties of orthophthalic PC

\begin{tabular}{|l|c|}
\hline Propiedades / Property & Valor / Value \\
\hline Resistencia a compresión / Compressive strength & $102 \mathrm{MPa}$ \\
\hline Módulo de compresión (E) / Compression modulus (E) & $30.492 \mathrm{MPa}$ \\
\hline $\begin{array}{l}\text { Compresión máx. Deformación } \\
\text { Total elong. at max. compression loading }\end{array}$ & $5.0 \%$ \\
\hline Módulo de Poisson / Poisson's modulus & 0.21 \\
\hline Resistencia en flexión / Flexural strength & $26.0 \mathrm{MPa}$ \\
\hline Módulo a flexión E / Flexural modulus (E) & $37.868 \mathrm{MPa}$ \\
\hline $\begin{array}{l}\text { Flexión máx. deformación } \\
\text { Total elong. at max. flexural loading }\end{array}$ & $0.98 \% 00$ \\
\hline
\end{tabular}

Por otro lado, a fin de evaluar el comportamiento mecánico del HP, otro hormigón polimérico diferente ha sido preparado y ensayado. Un HP basado en resina isoftálica cuya dosificación y propiedades básicas están incluidas en las Tablas 3 y 4.

Las Tablas 2 y 4 muestran los parámetros fundamentales de tensión-deformación, obtenidos bajo cargas a compresión y flexotracción, referidos al HP ortoftálico, previamente definido. En relación con los parámetros mecánicos analizados, el comportamiento del HP en compresión está caracterizado por una resistencia, módulo de Young y deformación última, mayores que en el HC. Este hecho, sumado a la forma menos "tendida" y menos parabólica de la curva tensión-deformación, permitiría afirmar que el HP también es un material más rígido en compresión que el HC (en condiciones de laboratorio).

En relación con los parámetros mecánicos de flexotracción (resistencia, módulo de Young y deformación última), esas mismas tablas caracterizan de manera unívoca la capacidad de los dos HP analizados, frente a los esfuerzos de flexión. Frente al $\mathrm{HC}$, el hormigón polimérico presenta una mayor capacidad mecánica en flexión (6). Es decir, la "reserva" mecánica que suponen los 26,0 MPa y 20,3 MPa, respectivamente, del HP poliéster ortoftálico e isoftálico supondrá una seguridad supletoria a añadir al armado necesario por condiciones de seguridad a fallo frágil.

De la comparación entre ambos HP, puede concluirse que las diferencias entre los parámetros mecánicos: resistencia, módulo y deformación, en flexión son mayores que en los respectivos en compresión. Por lo tanto, podría afirmarse que los ensayos de flexión son también interesantes, además de los de compresión, para clasificar y caracterizar mecánicamente los distintos tipos de HP. Hasta que se estandaricen diferentes clases resistentes, los materiales específicos precisarán de una amplia caracterización. Al igual que el HC, el HP tiene una resistencia a tracción relativamente baja, frente a su resistencia a
Tabla 3 / Table 3

Proporciones de mezcla de resina isoftálica Mix composition of isophthalic polyester concrete

\begin{tabular}{|l|c|}
\hline $\begin{array}{l}\text { Componentes } \\
\text { Component }\end{array}$ & $\begin{array}{c}\text { HP isoftálico } \\
\text { Isophthalic PC }\end{array}$ \\
\hline $\begin{array}{l}\text { Mezcla de resina de poliéster } \\
\text { Polyester resin mix }\end{array}$ & $12.3 \%$ \\
\hline $\begin{array}{l}\text { Finos de carbonato }(0.05 \text { a } 0.2 \mathrm{~mm}) \\
\text { Carbonate aggregate fines }(0.05-0.2 \mathrm{~mm})\end{array}$ & $22.0 \%$ \\
\hline $\begin{array}{l}\text { Arena fina de cuarzo }(0.2 \text { a } 0.5 \mathrm{~mm}) \\
\text { Fine quartz sand }(0.2-0.5 \mathrm{~mm})\end{array}$ & $50.5 \%$ \\
\hline $\begin{array}{l}\text { Arena de cuarzo }(0.5 \text { a } 5.6 \mathrm{~mm}) \\
\text { Quartz sand }(0.5-5.6 \mathrm{~mm})\end{array}$ & $15.2 \%$ \\
\hline
\end{tabular}

A second polymer concrete was prepared and tested to evaluate $P C$ mechanical behaviour. This second material was made from an isophthalic resin whose dosage and basic properties are given in Tables 3 and 4.

The fundamental compression and flexural stress-strain parameters for the orthophthalic $P C$, in turn, are given in Tables 2 and 4. Under compression, the PC exhibited higher strength, Young's modulus and strain to fracture than CC. This, together with the shape of its stress-strain curve, less "flat" and less parabolic, indicates that the PC is also a stiffer material under compression than CC (under laboratory conditions).

The flexural strength parameters in these same tables (strength, Young's modulus and strain to fracture) also unequivocally confirm the capacity of the PCs analyzed to withstand bending moment. Indeed, polymer concrete has higher bending strength than CC (6). That is to say, the mechanical "reserve" contained in the 26.0 MPa and 20.3 MPa found for orthophthalic and isophthalic PC, respectively, enlarges the margin of safety against brittle failure provided by the reinforcement.

A comparison of the two PCs shows that the differences in the values of their mechanical parameters - strength, modulus and strain- are greater under bending than under compression stress. Flexural strength tests can therefore supplement compressive strength trials for mechanically classifying and characterizing the different types of PCs. Until such time as the strength classes are standardized, specific materials will need to be extensively characterized. Like CC, PC has relatively low tensile strength compared to its compressive strength. The most effective analysis can be seen in the stress-strain 


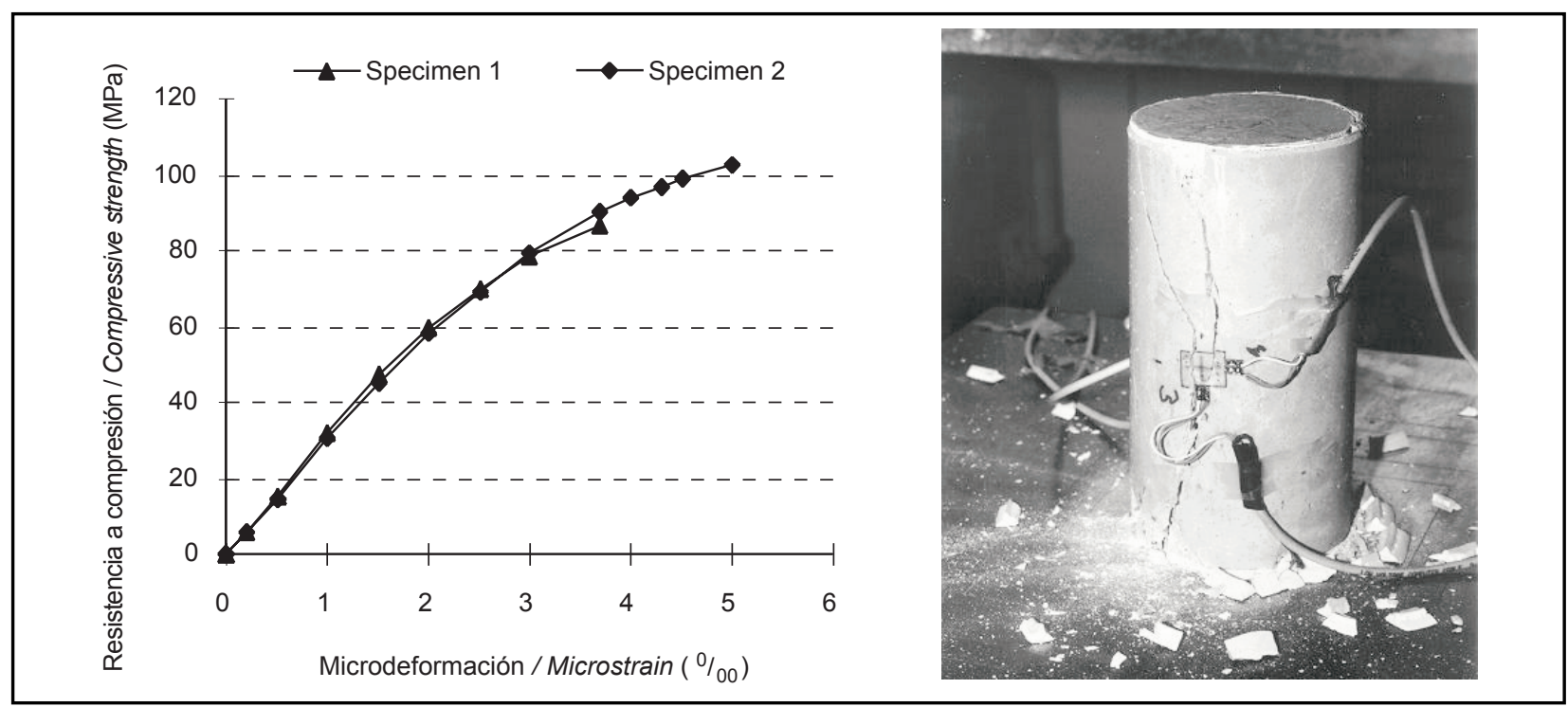

Figura 4. Curva de tensión-deformación para el CP (izquierda) y fotografía de la muestra (derecha).

Figure 4. Compression stress-strain curve for PC (left) and photograph of test specimen (right).

compresión. El análisis más efectivo puede observarse en la curva tensión vs. deformación mostrada en la Figura 4, asimilada a la forma de un polinomio de segundo grado. Este ensayo se ha desarrollado con probetas cilíndricas de tamaño $\varnothing 100 \times 200$ mm, aplicado a dos probetas.

Por lo tanto, con el objeto de aprovechar las ventajas resistentes del HP y, por otro lado, aumentar su ductilidad y tenacidad, en muchas aplicaciones podría ser necesario añadir acero de refuerzo en las zonas de tracción. Para valorar todos estos extremos, se hace necesario obtener las curvas tensión-deformación a flexión (Figura 5), asimilada a la forma lineal, se realizaron varios ensayos, según tres probetas prismáticas de $40 \times 40 \times 160 \mathrm{~mm}$.

Debido a la presencia del aglomerante resina polimérica, el HP tendrá un carácter viscoelástico y de naturaleza orgánica, que anticipan que será necesario manejar tanto los conceptos de cargas permanentes (deformaciones diferidas) y cargas vivas (deformaciones instantáneas), además de la influencia de la temperatura, mediante la definición de diagramas de cálculo basados en geometrías lineales-rectangulares, similares a las experimentales, anteriormente obtenidas (13). Del mismo modo a como se propone para el $\mathrm{HC}$, se debería emplear diagramas sencillos (14) en los que se incluya la temperatura real y las condiciones de carga para la estructura a diseñar. Estos aspectos fundamentales deberían establecerse a futuro, como resultado de un gran número de experimentos, aplicando ensayos de fluencia bajo cargas de compresión y flexión pura.

Como consecuencia de la estructura cerrada de poros del $\mathrm{HP}$, constatada en la Figura 3, la transmisión interna de curve given in Figure 4, which adopts a shape similar to the curve for a second degree polynomial. This curve was plotted from the results of the test conducted on two cylindrical specimens measuring $100 \varnothing \times 200 \mathrm{~mm}$.

Consequently, in many applications reinforcing steel may be needed in the tensile areas to capitalize on $P C$ strength and increase its ductility and toughness. As flexural stress-strain curves (which proved to be nearly linear, see Figure 5) were needed to assess these two questions, several trials were run with $40 \times 40 \times 160-\mathrm{mm}$ prisms.

The presence of the polymer resin binder in PC affords the material visco-elastic properties of an organic origin. Hence account must be taken of both permanent (deferred deformation) and live (instantaneous deformation) loads and the effect of temperature, by defining design diagrams based on linear-rectangular geometries similar to the graphs found in prior experiments (13). Simple diagrams such as proposed for CC (14) should be used, including the real temperatures and loading conditions to which the structure is to be exposed. Such fundamental aspects should be established in future on the basis of a large number of experiments, including creep trials under pure compression and bending loads.

As a result of the closed pore system in PC (Figure 3), the internal transmission of stress between the organic 
Tabla 4 / Table 4

Propiedades mecánicas del HP isoftálico Mechanical properties of isophthalic PC

\begin{tabular}{|lc|}
\hline Propiedades / Property & PC isoftálico / Isophthalic PC \\
\hline $\begin{array}{l}\text { Resistencia a compresión } \\
\text { Compressive strength }\end{array}$ & $91.9 \mathrm{MPa}$ \\
\hline $\begin{array}{l}\text { Módulo de compresión (E) } \\
\text { Compression modulus (E) }\end{array}$ & $24.863 \mathrm{MPa}$ \\
\hline $\begin{array}{l}\text { Compresión más, deformación } \\
\text { Total elong. at max. compression load }\end{array}$ & $5.9 \%$ \\
\hline $\begin{array}{l}\text { Módulo de Poisson } \\
\text { Poisson's modulus }\end{array}$ \\
\hline $\begin{array}{l}\text { Resistencia en flexión } \\
\text { Flexural strength }\end{array}$ \\
\hline $\begin{array}{l}\text { Módulo de flexión (E) } \\
\text { Flexural modulus (E) }\end{array}$ \\
\hline $\begin{array}{l}\text { Deformación máx. de flexión } \\
\text { Total elong. at max. flexural loading }\end{array}$ \\
\hline
\end{tabular}

las tensiones entre la matriz orgánica, compuesta por la resina poliéster y los finos, y los áridos gruesos, resulta más eficiente que en la estructura de poros abierta, más tradicional, del HC (15). Precisamente por la presencia del agua durante el proceso de hidratación del cemento, se genera una red de poros interconectados que causa la debilidad mecánica del HC, frente a las elevadas propiedades obtenidas en los dos tipos de HP estudiados.

En relación con las características de la porosidad del HP, frente al $\mathrm{HC}$, se han obtenido menores tamaños de poro, así como un contenido menor, que justifican también la mayor resistencia y rigidez del HP frente al HC (11), obtenidas según las curvas de tensión-deformación del HP.

\section{CONCLUSIONES}

- El hormigón polimérico analizado corresponde a un hormigón de uso estructural. Comparado con el hormigón ordinario, presenta una interfase compacta formada por una gruesa capa de resina que envuelve los áridos. Por lo tanto, este HP presenta una alta continuidad de transferencia de cargas y, consecuentemente, mostrará un comportamiento mecánico mejorado.

- La porosidad cerrada presente en el HP hace de éste un material atractivo para la obtención de estructuras de gran durabilidad. La continuidad de la microestructura, además de la naturaleza orgánica del aglomerante, facilita la protección de los elementos del HP contra los agentes atmosféricos, la corrosión y los ataques químicos, haciendo necesario un menor recubrimiento que el hormigón de cemento Portland.

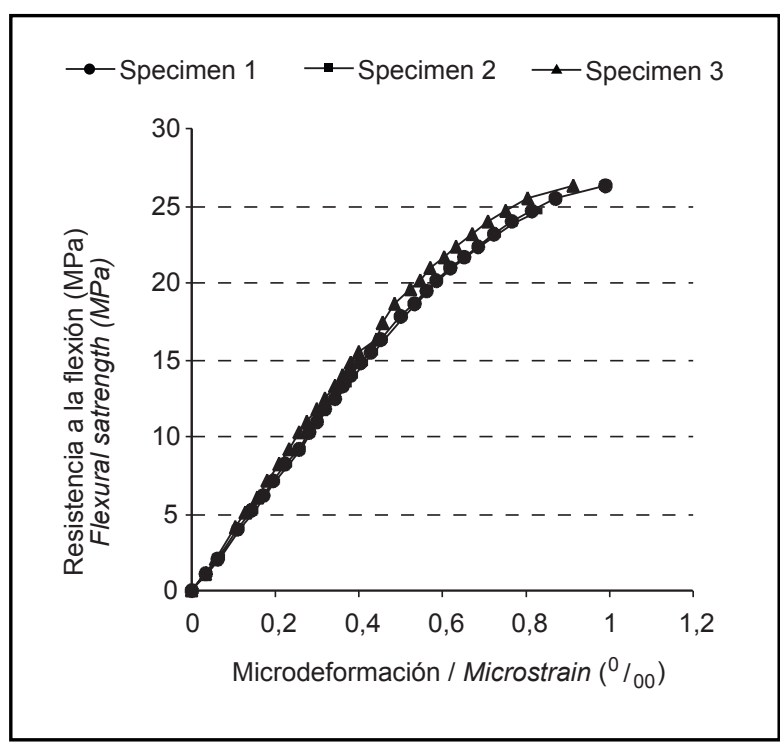

Figura 5. Curvas tensión vs. deformación en flexión del HP. Figure 5. Flexural stress-strain curve for $P C$.

matrix, consisting in polyester resin and fine aggregate, and the coarse aggregate is more efficient in this material than in the more traditional CC with its open pore structure (15). The presence of water during ordinary cement hydration generates a network of interconnected pores that are responsible for the relative mechanical weakness of CC compared to the two PCS studied.

The lesser volume of smaller sized pores observed in the PC studied would explain the greater strength and stiffness of this material compared to CC (11) denoted in the respective stress-strain curves.

\section{CONCLUSIONS}

- The polymer concrete analyzed was designed for use in structural members. Compared to ordinary concrete, it has a compact interface consisting in a thick layer of resin that envelopes the coarse aggregate. Consequently, PC exhibits load transmission continuity and as a result high mechanical strength.

- Thanks to its closed microstructure, PC is ideal for high durability structures. The continuity of the microstructure, which along with the organic nature of the binder protects PC members against atmospheric agents, corrosion and chemical attack, translates into the need for a smaller concrete cover than in Portland cement concrete. 
- Respecto a las propiedades del HP, la porosidad, la configuración de la interfase árido-matriz, la resistencia y la deformabilidad están estrechamente relacionadas. Las ventajas de sus propiedades mecánicas, comparadas con las de los cementos ordinarios, generan optimismo para futuras tendencias en la construcción (resistencia a compresión 3 veces mayor que en el HC y resistencias mínimas a flexión de orden de $25 \mathrm{MPa}$ ).

- Mediante la comparación de diferentes HP se ha observado una gran sensibilidad de los parámetros de flexión (tensiones y módulo). Por lo tanto, el ensayo a flexión es otro procedimiento adecuado, además del ensayo a compresión, para clasificar los distintos tipos de HP, contrariamente a lo que ocurre en los hormigones de cemento, que sólo se ciñe a las resistencias de compresión.
- The various properties of PC - porosity, aggregatematrix interface, strength and deformability- are closely related. Its higher mechanical performance compared to ordinary cement generates optimism for future construction trends (compressive strength three times greater than in CC and minimum flexural strength values on the order of $25 \mathrm{MPa}$ ).

- The comparison of the two PCs showed that flexural parameters (stress and modulus) are highly sensitive. Therefore, in addition to the compressive strength test, the flexural test is an appropriate procedure for classifying different types of PCS, which differ in this regard also from CC, which is classified solely on the basis of compressive strength.

\section{BIBLIOGRAFÍA / BIBLIOGRAPHY}

(1) European Project BRPR-0CT98-078: Highly durable precast special concrete reinforced with non-metallic rebars, Plasticrete, febrero, 2002.

(2) Fowler, D. W.: "Polymers in Concrete - Where have we been and where are we going?", en D. Fowler (ed.): Proceeding ICPIC'01, Hawai, 2001.

(3) Verleg, R. L.: "Corrosion resistant unsaturated polyester resins; an overview, by DSM-BASF Structural Resins", Proceedings of the Reinforced Plastics Conference, Karlovy Vary, 1997, pp. 90-100.

(4) Czarnecki, L., Garbacz, A. y Lukowski, P., Clifton, J.: Optimization of polymer concrete composites, NISTIR 636, Maryland, 1999.

(5) Nanni, A.: "North American design guidelines for concrete reinforcement and strengthening using FRP: principles, applications and unresolved issues", en J. G., Teng (ed.): Proceedings of the International Conference on FRP Composites in Civil Engineering, HongKong, vol. 1 (2001), pp. 61-72.

(6) San-José, J. T. y Vegas, I.: "Find Meyer. Structural analysis of FRP reinforced polymer concrete material", Constr. Build. Mater., 20 (2006), pp. 971-981.

(7) San-José, J. T., Vegas, I. y Ferreira, A.: "Reinforced polymer concrete: physical properties of the matrix and static/dynamic bond behaviour", Cem. Concr. Compos., 27 (9-10) (2005), pp. 934-944.

(8) Czarnecki, L., Garbacz, A., Lukowski, P. y Clifton, J.: Optimization of polymer concrete composites. NISTIR 636, Maryland (USA), agosto, 1999.

(9) RILEM: Symposium on properties and tests methods for concrete-polymer composites, Oostende, 1995.

(10) Olivares, M., Laffarga, J., Galán, C. y Nadal, P.: "Evaluation of concrete mechanical strength through porosity", Mater. Construcc., 54 (273) (2004), pp. 21-34.

(11) Spanish Instruction EHE. In Spanish, 1999.

(12) Abdel-Fattah, H. y El-Hawary, M. M.: "Flexural Behaviour of Polymer Concrete", Constr. Build. Mater., 13 (1999), pp. $253-262$.

(13) San-José, J. T. y Aguado, A.: "Influence of the viscoelastic nature of the polymer concrete in its structural behaviour", en University of Minho (ed.): Proceedings of the International Symposium Polymers in Concrete. ISPIC'06, Guimaraes, 2006, pp. 69-83.

(14) Kwan-ho kim, Kyu-seok yeon, Nan-ji jin y Kwang-soo park: The investigation of the equivalent rectangular stress block for highstrength polymer concrete beams, ICPIC'01 Hawai (USA), 2001.

(15) Van Gemert, D., Knapen, E., Czarnecki, L. y Lukowski, P.: "Cement concrete and concrete Polymer composites: two merging worlds. A report from $11^{\text {th }}$ ICPIC Congress in Berlin, 2004", en University of Minho (ed.): Proceedings of the International Symposium Polymers in Concrete. ISPIC'06, Guimaraes (2006) pp. 1-15. 